\title{
“Dorang (Dolan Semarang)" Game Solution to Introduce Semarang Municipality and Semarang Regency as Tourist Attraction
}

\author{
Lidya Oktorina Kusuma Sakti \\ Department of Information System, Faculty Computer Science, \\ Soegijapranata Catholic University, Semarang, Indonesia, 50234 \\ lidyaoktorina@gmail.com \\ T. Brenda Chandrawati, ST., MT.,IPM. \\ Department of Information System, Faculty Computer Science, \\ Soegijapranata Catholic University, Semarang, Indonesia, 50234 \\ brenda@unika.ac.id
}

\begin{abstract}
Tourism is the activity of people travelling in a short period of time into a tourist attraction to relax and refresh the mind. Tourists will feel convenient if visiting the tourist attraction. One of the cities that have many tourist attractions is Semarang municipality and Semarang regency. Semarang municipality and Semarang regency have a natural, social and cultural attractions, travel games, agro tourism, and culinary tours. Based on a study, $64 \%$ of 30 respondents who are 15-30 year old domestic travelers did not know the locations of tourist attraction in Semarang municipality and Semarang regency. Due to the little knowledge of domestic travelers, "DORANG (Dolan Semarang)" is made so that this game can be used as a guide to travel and as a media for promoting these attractions. This game contains a map of Semarang municipality and Semarang regency along with the information of tourism sites. After respondents are finished playing this game, they will know the information of tourism sites in Semarang municipality and Semarang regency better and also recognize these attractions.
\end{abstract}

Keyword: tourism, tourism map, game

\section{INTRODUCTION}

Semarang municipality and Semarang regency are places that have a huge tourism potential. There are various attractions there in either form of natural, cultural, religion, and culinary attractions. But it turns out that many domestic tourists do not know these sites, for example, Gedong Songo temple. This temple is one of the Hindu cultural relics in Semarang regency. Gedong songo temple is less famous than Dieng temple. According to Statistics Central Agency Semarang Regency in 2014 the number of visitors of Gedong Songo temple was 299.141 visitors which was less than the number of visitors at the Dieng temple [2]. Seeing that the problem is fewer number of travelers that know tourism in Semarang municipality and Semarang regency and the development of increasingly advanced game technology then a single android based game themed tourism that aims to introduce various attractions of Semarang municipality and Semarang regency is made. Therefore, this article will discuss the process of making games ranging from the creation of GUI (Graphic User Interface) design games, programming games, until the game is finished and can be published. 
“Dorang (Dolan Semarang)” Game Solution to Introduce Semarang Municipality and Semarang Regency as Tourist Attraction

\section{LITERATURE REVIEW}

\subsection{Tourism}

According A.J. Burkart and S. Medlik, tourism is the transfer of the person for a while and in a short period of time to destinations outside the places where they normally live and work, and their activities are different during their stay in the destination [3].

According Fandeli, tourism is anything associated with tour, including business objects of tourist attraction as well as related to efforts in the field. Tourism is an activity of travelling from one place to another for a vacation [4].

Then it can be concluded that in general the tourism is the process of departure of a person in a short period of time to the tourist attraction with the aim to refresh the mind. In addition, tourism is also aimed as a means to get to know more tourist attractions in the city and out of town.

\subsection{Tourism Map}

Tourism map is a map that illustrates and explains various tourist locations in the city and outside the city. Tourist map contains information about the attractions and the promotion of tourism in both the city and regency. Tourist map can be displayed in the form of animation, text, and graphics [5].

\subsection{Game}

According to Nilwan, Agustinus (1996), in his book "Pemrograman Animasi dan Game Profesional”, game is a computer game created with animation techniques and animation methods. Game developer who wants to deepen the use of animation is required to understand the making of the game, or if game developers want to make a game, then it is necessary to understand the techniques and methods of animation as both of these are inter related [6]. Then it can be drawn the conclusion that the game is a game which has a variety of regulations in the way of playing, have a variety of strategies to solve the game. The game is also a medium of entertainment and learning. By playing a game then it can entertain players so players will experience the fun and satisfaction, not just entertaining, games can also be used as a medium of learning and media promotion.

\subsection{Software Used}

\subsubsection{Corel Draw X7}

Corel Draw X7 is an application program that is designed specifically for the purposes of graphic design especially for vector graphics editor. Corel Draw 7 has several advantages, namely to make the design of logos and symbols, because these applications have the ease of processing line and color, making images illustrations can be also done with Corel Draw 7 especially pictures with dominant arches, angular lines, and because it has a high level of accuracy of size. Corel Draw X7 application can also read all of the font so that it will be easy to explore the design and writing [7].

\subsubsection{Construct 2}

Construct 2 is software game engine based HTML 5 android based and is used to create a game that is easier and more interactive. Construct 2 was created without a lot of programming languages cause the system provided in the game engine this is a drag and drop, so the game engine of this Construct 2 can be used by anyone who is interested in developing games or other applications. Construct 2 can be run in Windows, Mac, Linux, and the Ipad [8].

\section{RESEARCH METHODS}

\subsection{Final Questionnaire}


The final questionnaire is carried out if the game is finished and the game is already made and tested by the 30 respondents who are domestic tourists. The purpose of this final questionnaire is to see if the game has already made successfully as one of the solutions to resolve problems in this research.

\subsection{Method of Making Games}

\subsubsection{Creation of GUI Design Game}

In the making of the game, the first thing to do is making the GUI design of the game. GUI design of this game is created with Corel Draw X7.

\subsubsection{Programming Game}

The process of making the game is in its entirety so that the game can be completed in determined time. In making games, the Construct 2 is used.

\subsubsection{Game Testing}

Game testing is done after the game is completed. Testing purpose of this game is to test that the game created there is no bug.

\subsubsection{Game Publication}

If the game was finished and tested and the result shows there is no bug. The game will be published with the uploaded file in the Playstore so that the community can download them for free.

\section{RESULT AND EXPLANATION}

\subsection{Making Game}

In the making of games using Corel Draw X7 software for designing background and asset needed in gaming and Construct 2 for programming game is used.

\subsubsection{GUI (Graphical User Interface)}

The GUI is an interface system on the game in the form of a graphical display men used in game GUI (Graphical User Interface) "DORANG (Dolan Semarang) as follows.

\section{a. Game Icon}

The icon of the games created with a size of 1024 px x 1024 px with a file png format. Icon games "DORANG (Dolan and Denok as the main cast. Icon games also display the title game.

\section{b. Splash Screen}

Splash screen in this game is the first display that appears and does the game load process that will run. The process of loading a game is marked by the existence of a loading bar, www.gametech.id text, and the background of the splash screen. This is a nick name of the maker game.

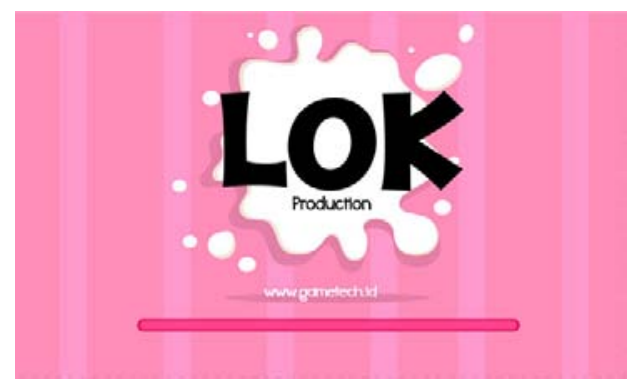

Figure 4.1 Splash Screen menu in "DORANG (Dolan Semarang)" game

\section{c. Main Menu}

Game "DORANG (Dolan Semarang)" main menu consists of the start menu options, how to play, and setting. After selecting start button then the player will be directed to next menu, if choosing how to play button then the player will see the steps in to play this game, and if selecting setting button then the player can set up active or not active from back sound and sound effect in games.

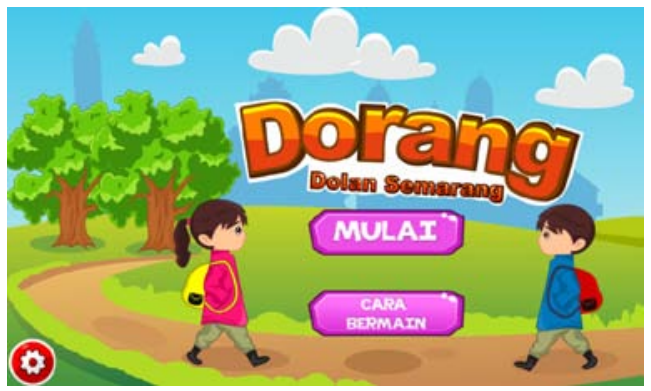

Figure 4.2 Main menu in "DORANG (Dolan Semarang)" game

\section{d. Menu Select Character}


“Dorang (Dolan Semarang)” Game Solution to Introduce Semarang Municipality and Semarang Regency as Tourist Attraction

Select character menu consists of 3 buttons namely Kenang select character button, Denok select character button, and home button. In the select character menu player can choose a character to play, and the home button is used if player wants to return to the main menu.

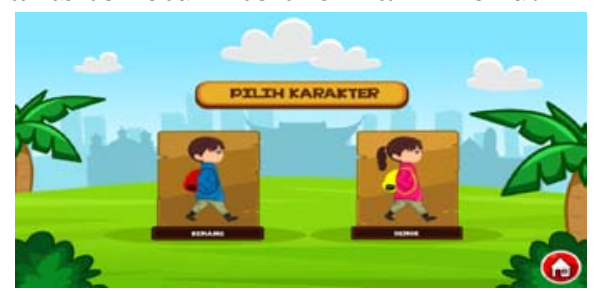

Figure 4.3 Menu select character in "DORANG (Dolann Semarang game

\section{e. Select City Menu}

Select city menu consist of 3 buttons namely Semarang municipality button, Semarang regency button, and back button. In this menu player can choose the city that will be played.

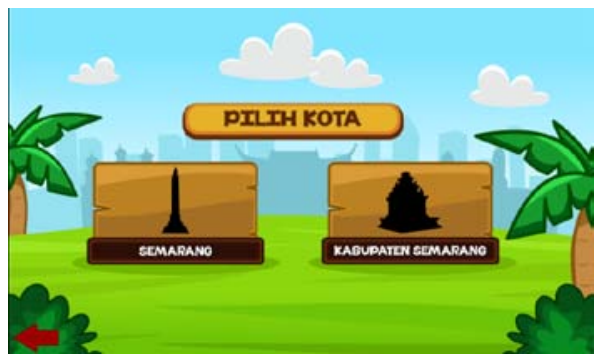

Figure 4.4 Menu select city in "DORANG (Dolan Semarang)” game

\section{f. Menu Tourist Map of Semarang and Semarang Regency}

In this menu there are 5 buttons of the optional attractions in Semarang municipality, 1 key stage open end and 4 key stage closed, so is the menu at Semarang regency.

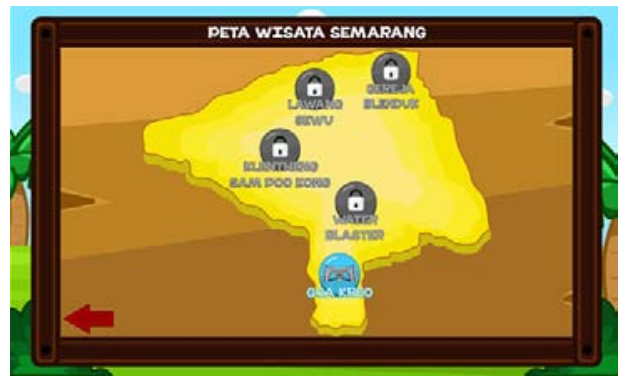

Figure 4.5 Menu of tourism map of Semarang municipality in "DORANG (Dolan Semarang)" game

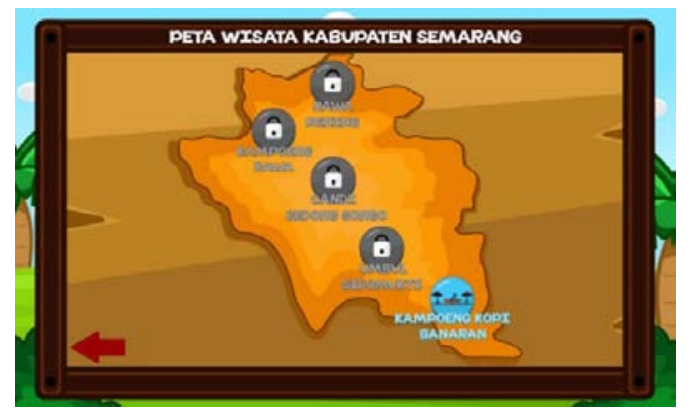

Figure 4.6 tourism map menu of Semarang regency in “DORANG (Dolan Semarang)”game

\section{g. Gameplay Menu}

"DORANG (Dolan Semarang)" game every stage is made to inroduce and promote the attractions of Semarang municipality and Semarang regency to tourists or wider community. This game consists of 10 stages and it contains different attractions, 5 stages consists of a stage attraction in Semarang municipality and 5 stage consists of a stage attraction Semarang regency. Each stage has similar background, attraction, asset, and the number coins collected are different in each stage.

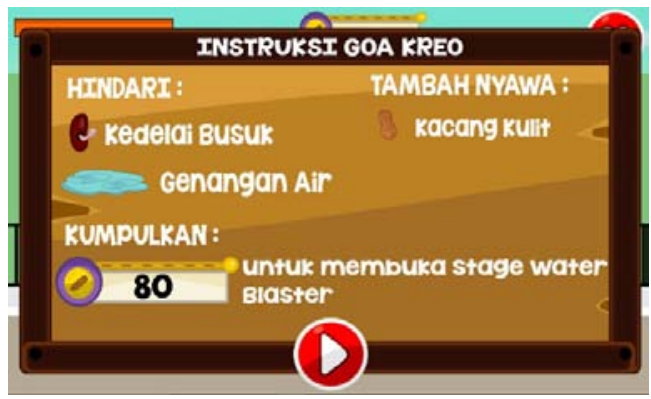

Figure 4.7 Display of “DORANG (Dolan Semarang)"game missions

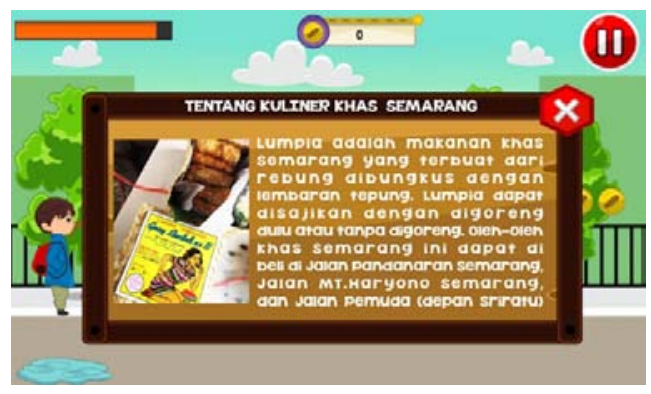

Figure 4.8 Display of culinary "DORANG (Dolan Semarang)"game information 


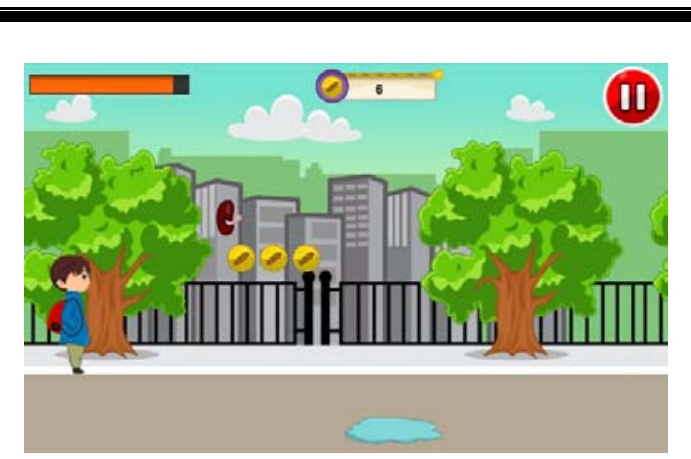

Figure 4.9 In game “DORANG (Dolan Semarang)" display

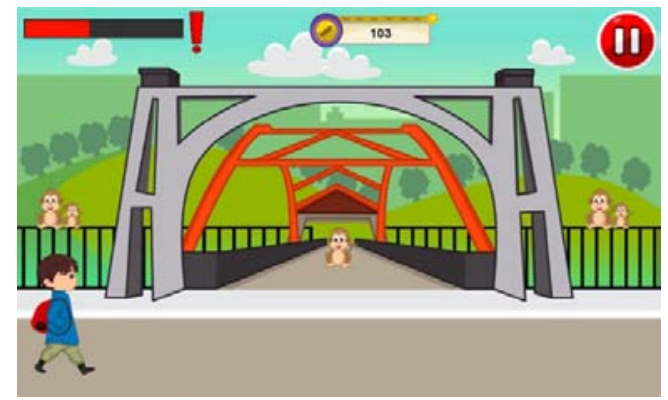

Figure 4.10 Display of attractions "DORANG (Dolan Semarang)" game

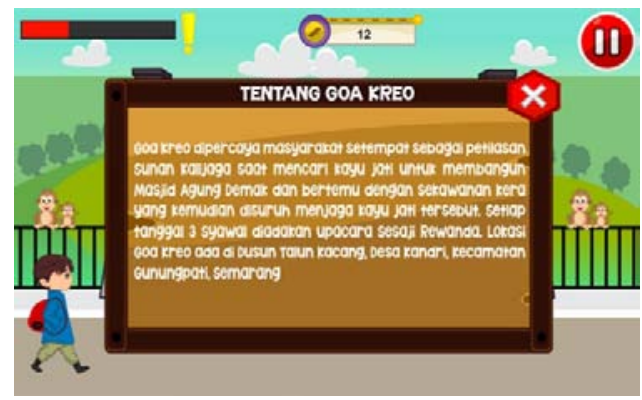

Figure 4.11 Display of attractions "DORANG (Dolan Semarang)” game information

\subsection{Programming Game}

Programming game "DORANG (Dolan Semarang)" uses a game engine Construct 2. Game programming is composed of GUI programming, HUD programming, and gameplay programming.

\section{a. GUI programming on the main} menu

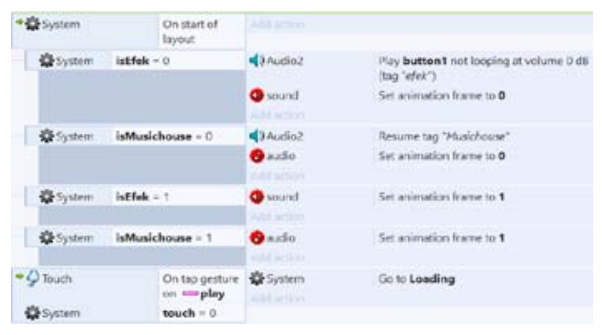

Figure 4.12 Example nrooram main monı oame
In Figure 4.12 is one example of the program main menu, such a program to the start button there is a condition of touch, on tap gesture on play that has a meaning if the start button is clicked then the player will enter main menu loading for waiting game begins.

\section{b. HUD Programming}

HUD programming consists of a health bar and score game programming. The examples of HUD programming is as follows :

\begin{tabular}{|c|c|c|c|}
\hline Syst... & Nyawa $1 \leq 0$ & System & Set time scale to 0 \\
\hline Syst... & Trigger once & —Sprite21 & Set width to Nyawa1 \\
\hline & & —Sprite21 & Destroy \\
\hline & & System & Set layer $\mathbf{5}$ Visible \\
\hline & & System & Set pause 1 to 2 \\
\hline
\end{tabular}

Figure 4.13 Example health bar and score game program

\begin{tabular}{l|l}
$\begin{array}{ll}\text { T.jotalcoin } & \text { Set text to lumpiacoin + lumpiacoin 1 + } \\
\text { lumpiacoin2 }\end{array}$ \\
$\begin{array}{l}\text { Set cointinggi to lumpiacoin + lumpiacoin 1 + } \\
\text { lumpiacoin2 }\end{array}$
\end{tabular}

Figure 4.14 Example program to calculate score games

\section{c. Gameplay Programming}

Game programming deals with the core of this game, at each stage the player must complete missions by avoiding obstacle, collecting coin, and collecting the life in order to survive until the destination. The following is a sample program from stage attractions Semarang municipality.

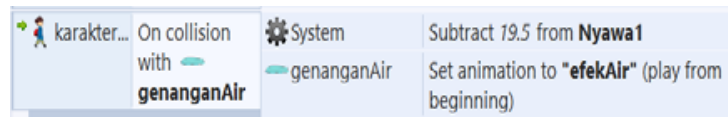

Figure 4.15 Example of program if the character is hit by a puddle then life will be reduced

$$
\begin{aligned}
& \text { - } \$ \text { karakte... On collision lumpiacoin } \\
& \text { with } \\
& \text { lumpiacoin }
\end{aligned}
$$

Figure 4.16 Example of program

if the character is hit by coins then the score will increase 
“Dorang (Dolan Semarang)” Game Solution to Introduce Semarang Municipality and Semarang Regency as Tourist Attraction

Based on the results of questionnaire processed end then it can be drawn the conclusion that the respondents after playing the "DORANG (Dolan Semarang)" game know the tourist attractions in Semarang municipality and Semarang regency better. Additionally through this game the respondents can also get information about the location of tourist attractions in Semarang municipality and Semarang regency, not just a tourist attraction, the respondents know about one of the charms of Semarang municipality and Semarang regency as example of culinary tour better. By analyzing the results of final questionnaire it can be said that the "DORANG (Dolan Semarang)" game can be one of the solutions in introducing attractions of Semarang municipality and Semarang regency.

\section{CONCLUSION}

It can be concluded that "DORANG (Dolan Semarang)" game is a game that can be used as one of the solutions in form of media to introduce tourist attractions in Semarang municipality and Semarang regency to tourists through tourist map view in it.

In addition, this game consists of 5 stage attractions in Semarang municipality and 5 stage attractions in Semarang regency accompanied with the information of tourist attractions to increase attraction for tourists in order to make a day trip in tourist attractions in Semarang municipality and Semarang regency.

\section{ACKNOWLEDGEMENT}

Lidya Oktorina Kusuma Sakti is student who received a scholarship from Ministry of National Education of Republic Indonesia (Beasiswa Unggulan Kemendikbud Republik Indonesia) and T.
Brenda Chandrawati, ST., MT.,IPM. is a lecturer teaching Information System study program of Soegijapranata Catholic University.

\section{REFERENCE}

[1] "Banyaknya Pengunjung di Tempat Rekreasi di Kabupaten Semarang Selama Tahun 2014 ." [Online]. Available https://semarangkab.bps.go.id/linkT abelStatis/view/id/151. [Accessed June-29-2016].

[2] "Liburan Wisatawan Ke Dieng Membludak." [Online]. Available: http://www.jatengprov.go.id/id/news room/liburan-wisatawan-ke-diengmembludak. [Accessed June-292016].

[3] A. J. Burkart and S. Medlik, "Tourism: past, present and future.," Tour. past, Present Futur., no. Ed. 2, 1981.

[4] C. Fandeli, Dasar-dasar Manajemen Kepariwisataan Alam. Yogyakarta: Penerbit Liberty, 1995.

[5] B. A. VENANDA, "Peta Wisata Interaktif Provinsi Jawa Tengah," Skripsi, Fak. Ilmu Komput., 2015.

[6] Nilwan, Agustinus. Pemrograman Animasi dan Game Profesional. Jakarta: Elex Media Komputindo, 1998.

[7] "Corel Draw adalah Editor Grafik Vector" [Online]. Available :http//gegliapwouet.blogspot.co.id/2 010/11/corel-draw- adalah-editorgrafik-vector.html?m=1. [Accessed April-10-2015].

[8] D. Bigelow, Construct Game Development Beginners Guide. Packt Publishing Ltd, 2012. 
"Dorang (Dolan Semarang)" Game Solution to Introduce Semarang Municipality and Semarang Regency as Tourist Attraction 